\title{
Application of the Quadratic Almost Ideal Demand System (QUAIDS) Model in the Demand of the Household Animal Sourced Food in West Java
}

\author{
Bayu Kharisma ${ }^{1}$, Armida S. Alisjahbana ${ }^{1}$, Sutyastie Soemitro Remi ${ }^{1}$, Putri Praditya ${ }^{2}$ \\ ${ }^{1}$ Department of Economics, Universitas Padjadjaran, Indonesia \\ ${ }^{2}$ Central Bureau of Statistics, Sumedang Regency, West Java, Indonesia
}

\begin{abstract}
This paper aims to determine the effect of demographic and socio-economic factors and household responses to household changes in prices and income against the demand for household animal-sourced food in West Java Province. The study used cross-section data sourced from the National Socio-Economic Survey (SUSENAS) of West Java Province in 2017 analyzed through the Quadratic Almost Ideal Demand System (QUAIDS). The results showed that the demand for household animal-sourced food in West Java was influenced by price, income, and social demographic factors. All groups of animal-sourced food were categorized as normal goods, as characterized by an income elasticity value of more than zero. The income elasticity established meat commodities as the highest with eggs being the lowest. The nature of the commodity determined that all animal-sourced food groups except eggs are luxury goods. Luxury goods are categorized as such due to their above one value of the demand response against changes in income- which in this paper refers to the commodities of fish, meat, poultry, and milk. The own-price elasticity also showed meat as the most responsive commodity to price increases compared to fish, poultry milk, and eggs. The five groups of commodities achieved a negative elasticity value, as reflected by the reduced share when the decreasing demand responds to the commodity price increase. The cross-price elasticity of most animal-sourced food commodity groups achieved negative elasticity values, which indicated that the related animal-sourced food commodity groups were complementary, whereas positive elasticity values indicate the related food commodities group as a substitute.
\end{abstract}

\section{Keywords}

West Java province, QUAIDS, animal sourced food, elasticity.

Kharisma, B., Alisjahbana, A. S., Remi, S. S. and Praditya, P. (2020) "Application of the Quadratic Almost Ideal Demand System (QUAIDS) Model in the Demand of the Household Animal Sourced Food in West Java", AGRIS on-line Papers in Economics and Informatics, Vol. 12, No. 1, pp. 23-35. ISSN 1804-1930. DOI 10.7160/aol.2020.120103.

\section{Introduction}

Protein, as an essential nutrient in the food and to the body, can be obtained from plant-sourced foods (vegetable protein) and animal-sourced foods (animal protein). However, animal protein has a complete amino acid composition and better digestibility when compared to vegetable protein. According to Soehadji (1993) in Ariningsih (2004), animal protein is an agent for the development of a nation and has indispensable properties. Meanwhile, Pakpahan (2018) stated that the low consumption of animal-sourced food is a significant factor in the high Global Hunger Index (GHI) in Indonesia. IFPRI (2016) stated that Indonesia is categorized as a country with a severe hunger rate with a GHI value of 22.0, only better than Cambodia, Laos, and Myanmar. Besides the Global Hunger Index (GHI), the overall food consumption can be seen from the Nutrient Adequacy Score (NAS). The Central Statistics Agency (BPS) data in 2017 showed that for the first time, the average consumption of calories and protein of Indonesian people have met nutritional adequacy standards, as seen in Table 1 below.

Table 1 shows that the Indonesian nutrient consumption has achieved sufficient standards for calories and protein, albeit still dominated by plant-sourced foods. The calory consumption derived from animals is $128.17 \mathrm{kcal}$ or $6 \%$ of total caloric intake, while protein derived from animals 


\begin{tabular}{|c|c|c|c|c|}
\hline \multirow{2}{*}{ Food Group } & \multicolumn{2}{|c|}{ Calories (kcal) } & \multicolumn{2}{|c|}{ Protein (gram) } \\
\hline & 2016 & 2017 & 2016 & 2017 \\
\hline Non-Animal sourced food & 1877.36 & 1975.28 & 42.81 & 46.41 \\
\hline Animal sourced food & 160.03 & 177.34 & 13.86 & 15.78 \\
\hline - fish & 42.88 & 49.17 & 7.17 & 8.23 \\
\hline - Meat & 56.02 & 67.70 & 3.35 & 4.20 \\
\hline - Eggs and Milk & 61.13 & 60.47 & 3.34 & 3.35 \\
\hline total & 2037.39 & 2152.62 & 56.67 & 62.19 \\
\hline
\end{tabular}

Source: Susenas, 2017

Table 1: Average daily consumption of calories and protein per capita according to the food group 2016-2017.

was $7.55 \mathrm{~g} /$ capita/day, which is $12.1 \%$ of the total protein intake. Meanwhile, when compared with the Food and Agriculture Organization (FAO) data in Balance livestock in 2009, the average animal-sourced calory and protein intake of countries in the world is $388.2 \mathrm{kcal}$ and $23.9 \mathrm{gr} /$ capita/day with each share of total intake being $12.9 \%$ and $27.9 \%$ respectively. The low consumption of animal-sourced food may discourage the quality improvement of Indonesian labor. Therefore, increasing consumption of animal protein is necessary for increasing the health and productivity of Indonesians, which consequently can improve the competitiveness of Indonesian labor in the international arena (Ministry of Health, 2015).

West Java Province is the largest consumer base in Indonesia; however, food remains a prevalent issue. BPS (2017) disclosed that the average calory consumption per capita in West Java was $2230.92 \mathrm{kcal} /$ day, and per capita, protein consumption reached 65.59 grams/day; the numbers categorized the consumption as reaching standards. However, plant-sourced protein still dominated that consumption, making the quality of food consumption low as indicated by the low score of Desirable Dietary Pattern (DDP), which is below the national DDP of $85.2 \%$. The Election Organization Ethics Council (DKPP, 2018) has argued that one cause of the low score of DDP in West Java is due to the community's high dependence on staple foods and the low consumption of animal-sourced foods. Until now, the Energy Adequacy Level (EAL) is still dominated by rice food groups, with grains amounting to $58.9 \%$ which is above the $50 \%$ ideal level when based on the ideal standard of DDP 100. The ricedominated consumption patterns of society may cause a high contribution of rice EAL.

The government's burden in improving the quality of human resources is parallel to the population increase. Thus, comprehensive efforts are needed to prevent these obstacles from interfering with future development in West Java Province. The government continuously conducts programs to improve the quality of human resources, among others, by improving and increasing the nutritional status of the community. Therefore, an exhaustive analysis of the food demand, especially animalsourced food, is required, in terms of factors the demand, as well as consumer responses towards changing prices and income.

Some previous studies of food demand state that there is a relationship between income, own prices and other food prices on household consumption of food. Burger et al (2017) in their research find substantial variation in the price and income elasticities of demand for items across the income distribution, with the bottom quartile being extremely sensitive to increases in the price of food and clothing items, and the top quartile being as sensitive as households in developed countries. Hoang and Glewwe (2011) investigated the impact of an increase in food prices on welfare and poverty rates in Vietnam. The results showed that a $20 \%$ price increase in all products, assuming that consumer and producer prices rise proportionally, resulted in an increase in household expenditure by up to $3.4 \%$. If the producer's price is higher than the consumer's price, the agricultural household's welfare will improve. Pangaribowo and Tsegai (2011) found a high income or expenditure elasticity for milk, meat and fish food goups, especially in poor households. Ravallion and Van der Walle (1991) indicated that a $10 \%$ increase in food prices had an impact on severe poverty in Indonesia. Bopape and Myers (2007) on household-level food demand in South Africa, presented differences in households consumption patterns in the rural and urban areas as well as households at each income level. 
The research identified meat and fish as luxury items in all household income level groups. Thus, the purpose of this study, in particular, is to identify the socioeconomic, demographic factors influencing the demand for animal-sourced food in West Java Province and determining the income elasticity, own price elasticity and cross-price elasticity of demand for animal-sourced food in West Java.

This research provides important empirical contributions, where previous studies on food demand are more concerned as food as a whole in a national scope. Meanwhile, this study will be more specific and analyze animal sourced food and protein and divide it into five food groups, namely fish, meat, poultry, eggs and milk at the provincial level, namely West Java with the Quadratic Almost Ideal Demand System (QUAIDS) model.

\section{Materials and methods}

This study will use secondary data collected by the Central Statistics Agency (BPS), namely KOR and Expenditure Consumption (KP) in the socio-economic survey (SUSENAS) and applying the Quadratic Almost Ideal Demand System (QUAIDS) model. For data processing, Stata 14.2 is used to estimate the models. This model can maintain consistency with the Engel curve and the effect of relative prices in utility maximization. Additionally, this model allows more parameters to be predicted compared to previous models such as LA/AIDS (Aepli, 2014). This model requires all sample households to consume all the studied commodities. Anticipating zero consumption can be done by incorporating groups of commodities or food into a larger group should there still be zero consumption, the Inverse Mills Ratio (IMR) variable is added as an independent variable. The IMR variable is obtained by performing a two-step estimation from the Heckman test (Widarjono and Rubcha, 2016; Mayasari, Satria and Noor, 2018)).

The disadvantage of using household survey data is its lack of price for the commodities consumed. Price (unit value) is obtained by dividing the value issued by the quantity purchased. This method can be used for research in small areas with more homogeneous demographic factors. According to Zheng and Hennebery (2010), should the research be conducted in large areas with varying demographic factors, the unit value approach will contain several errors, one of which will result in biased measurements. To overcome this problem, the price variable in this study utilized the unit values corrected by the price differential method as done by Majumder, Ray and Kompal (2012). The unit value is corrected by adding the district/ city middle value and estimated residual regression difference in the middle value of each district/ city with social demographic factors. This method assumes households in the same district/city to face the same commodity prices. Mathematically, it can be written as follows:

$$
\begin{aligned}
v_{i}-v_{\text {median }}= & \alpha_{0}+\alpha_{1} \text { dloc }_{i}+\alpha_{2} \text { hsize }_{i}+\alpha_{3} \text { dgender }_{i} \\
& +\alpha_{4} \text { educ }{ }_{i}+\alpha_{5} i n c_{i}+\varepsilon_{i}
\end{aligned}
$$

correction prices are formed from the sum of the average value per unit of commodity group at the commodity and residual level:

$\left(p_{i}\right)_{\text {median }}=\left(v_{i}\right)_{\text {median }}+\left(\hat{e}_{i}\right)_{\text {median }}$

The generated price assumes that every household in one district/city experience the same market price for each item. The price is not affected by the endogeneity problem caused by different quality factors among households in a group (Majumder, Ray and Kompal, 2012). The equation for estimation in this study is the model developed by Ray (1983) and Poi (2012), where the QUAIDS equation becomes:

$$
\begin{aligned}
w_{i} & =\alpha_{i}+\sum_{j=1}^{n} y_{i j} \ln p_{j}+\beta_{i} \ln \left\{\frac{x}{a(p)}\right\}+\frac{\lambda_{i}}{b(p)}\left[\ln \left\{\frac{x}{a(p)}\right\}\right]^{2} \\
& +\alpha_{i 1} \text { dloc }_{i}+\alpha_{i 2} \text { hsize }_{i}+\alpha_{i 3} \text { dgender }_{i}+\alpha_{i 4} \text { educ }_{i} \\
& +\alpha_{i 5} \text { inc }_{i}+a_{i b} I M R+\varepsilon_{i}
\end{aligned}
$$

where:

$w_{i}=$ expenditure share from animal sourced food groups to $i$

$\ln p_{j}=$ the aggregate price of the $\mathrm{j}$-animal sourced food commodity group

$\mathrm{x}=$ household expenditure for animal sourced food consumption

$\ln (a / p)=$ price index

$b(p)=$ price aggregator

$d l o c=$ location $($ urban $=1)$

hsize $=$ household size

$d s e x=$ head of household sex $($ male $=1)$

educ $=$ years of schooling

Inc $=$ income group (low income group $=1$ as reference category, middle income group $=2$, high income group $=3$ )

$I M R=$ inverse mills ratio 
There are three types of demand elasticity that can be derived from the QUAIDS model. The three elasticities are as follows:

1. Income elasticity

$\mu_{i}=1+\frac{1}{w_{i}}\left[\beta_{i}+\frac{2 \lambda_{i}}{b(p)}\left\{\ln \left(\frac{x}{a(p)}\right)\right\}\right]$

2. Marshallian price elasticity (Uncompensated price elasticity)

$$
\begin{aligned}
\varepsilon_{i j}^{N C} & =\frac{1}{w_{i}}\left[\gamma_{i j}-\mu_{i}\left(\alpha_{j}+\sum_{k=1}^{n} \lambda_{j k} \ln p_{k}\right)\right. \\
& \left.-\frac{\lambda_{i} \beta_{j}}{b(p)}\left\{\ln \left(\frac{x}{a(p)}\right)^{2}\right\}\right]-\delta_{i j}
\end{aligned}
$$

3. Compensated price elasticity

$\varepsilon_{i j}^{C}=\varepsilon_{i j}+\mu_{i} w_{j}$

where:

$\varepsilon_{i j}=$ price elasticity

$\gamma_{i j}=$ parameter of animal-sourced food prices

$\beta_{i}, \lambda_{i}=$ linear and quadratic parameters of income

$W_{i}=$ average share of animal-sourced food expenditure

$\delta_{i j}=$ the delta kronecker is zero for the own price $(i=j)$ and worth 1 for the cross price $(i \neq j)$

\section{Results and discussion}

\section{Allocation of household expenditures in West Java province}

The demand level for food and non-food consumption is highly dependent on the socioeconomic characteristics of each region. The urban and rural classification identified a difference of share in the average monthly expenditure for food and non-food households. The average food expenditure share (food share) in rural and urban areas households was $60 \%$ and $49 \%$ of the total household expenditure, respectively. The result showed that the expenditure majority in rural areas were food, while urban areas had a majority of non-food groups, as seen in Figure 1.

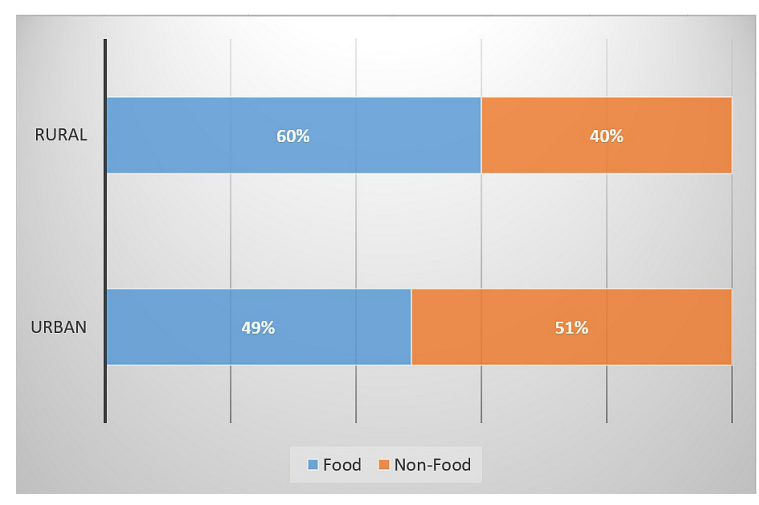

Source: Own calculation based on data from Susenas, 2017

Figure 1: The share of household expenditures in West Java province $(\%)$.

The difference in the share of expenditure between urban and rural areas was based on income, i.e., the income in urban areas tend to be relatively higher than rural areas. Previous studies also supported the research of Bopape (2007) and Mittal (2010) which stated of a substantial difference in rural and urban household's consumption patterns; urban households had higher expenditure budgets than rural households.

In addition to regional differences, the education level of the head of the household influenced the household expenditure priority. Head of household $(\mathrm{HoH})$ with less than or equal to 9 years of age (basic education) allocated $58.35 \%$ of their expenditure for food, and $41.65 \%$ for non-food items. In contrast, the head of households with more than nine years of education allocated greater expenditure for non-food items; $57.41 \%$, while food was only allocated with $42.59 \%$, as shown in Table 2 . This is in line with the research conducted by Mayasari, Satria \& Noor (2018), which stated that the education of the head of the household plays an essential role in determining the share of household food expenditure. This study also mentioned that the higher the education of the head of the household, the more the head of the household is concerned about food quality consumed by the household.

\begin{tabular}{ccccc}
\hline \multirow{2}{*}{$\begin{array}{c}\text { Years of Schooling } \\
\text { of Head of Household }\end{array}$} & \multicolumn{3}{c}{ Expenditure Group } \\
\cline { 2 - 5 } & \multicolumn{2}{c}{ Food } & \multicolumn{3}{c}{ Non-food } \\
\cline { 2 - 5 } & Value (rupiah) & $\%$ & Value (rupiah) & $\%$ \\
\hline$<=9$ & $1,651,303$ & 58.35 & $1,178,829$ & 41.65 \\
$>9$ & $2,578,218$ & 42.59 & $3,475,034$ & 57.41 \\
\hline
\end{tabular}

Source: Own calculation based on data from Susenas, 2017

Table 2: Household expenditures by education level in West Java province 2017. 
Meanwhile, the level of income significantly impacted the allocation of household expenditure. The higher the level of household income, the lower the share of food expenditure; inversely the expenditure share on non-food items will increase along with the increase in income. Households in the low and middle-income groups spent over $50 \%$ of expenditures for food, on the other hand, households in the high-income groups spent more than $50 \%$ of expenditure for non-food items, as seen in Table 3. Similar results were found in Abdulai's research (2002), which argued that future increase in income would shift the consumption pattern towards non-food items. This research is in line with Zheng and Henneberry (2010), which stated of different expenditure patterns of food demand in each income and distribution level of a community in a region.

Furthermore, food consumption was categorized into the consumption of animal-sourced food and non-animal-sourced food. Figure 2 shows that the expenditure share of the animal-sourced food is highest in the fish commodity group, amounting to $36 \%$ while the lowest is the meat commodity group with $7 \%$.

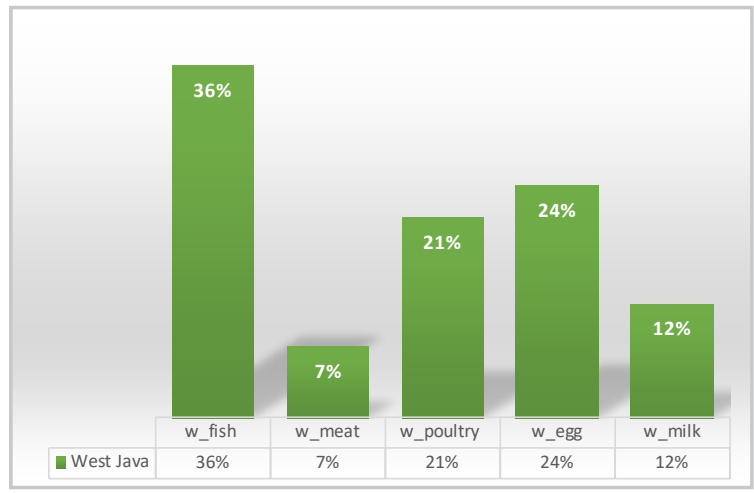

Source: Own calculation based on data from Susenas, 2017

Figure 2: Share of household animal sourced food expenditures in West Java (\%)

Animal-sourced food expenditures in urban and rural households in West Java were different.
Urban households spent $17.69 \%$ of the total food expenditure for animal-sourced food, while rural households only spent $14.24 \%$, as seen in Table 4 . This showed that households in urban areas have more means to consume animal-sourced food than rural households. This result is in line with the Molina and Gil (2005) which stated that the influence of residential locations provides a positive response to the expenditure share, they also stated that urban areas households tend to have higher incomes than people in rural areas.

Additionally, animal-sourced food expenditures in households in West Java showed that the higher the level of education, the higher the expenditure on animal-sourced food. Households with $\mathrm{HoH}$ of over nine years of schooling will spend almost $20 \%$ of their food expenditure on animal-sourced food, as seen in Table 5. This result is in line with Molina and Gil (2005) which stated that demand by consumers is not only influenced by price and income but also by other variables, one of which is perception/information of the product quality.

Household income also affected the expenditure of animal-sourced food. The Susenas data in 2017 showed that the low and middle-income households only spent $13-14 \%$ of total food expenditure for animal-sourced food, while highincome households used $20 \%$, as shown in Table 6 . This comparison means that the higher the level of income, the higher the expenditure on animalsourced food. This is also in line with the research conducted by Pangaribowo and Tsegai (2011) regarding consumption patterns in Indonesia. The research stated that households with the lowest income had the highest expenditure for staple foods and a small possibility for consuming dairy products, whole relatively high-income households allocated most of their food expenditure for food other than staple foods, namely plant-sourced food, meat and fish and dairy products.

\begin{tabular}{|c|c|c|c|c|}
\hline \multirow{3}{*}{ Income Level } & \multicolumn{4}{|c|}{ Expenditure Group } \\
\hline & \multicolumn{2}{|c|}{ Food } & \multicolumn{2}{|c|}{ Non-food } \\
\hline & Value (rupiah) & $\%$ & Value (rupiah) & $\%$ \\
\hline Low & $1,206,015$ & 65.68 & 630,060 & 34.32 \\
\hline Medium & $2,098,544$ & 57.00 & $1,583,400$ & 43.00 \\
\hline High & $3,138,808$ & 37.81 & $5,161,773$ & 62.19 \\
\hline
\end{tabular}

Source: Own calculation based on data from Susenas, 2017

Table 3: Household expenditures by income level and household animal sourced food consumption in West Java province 2017 (\%) 


\begin{tabular}{lccccc}
\hline \multirow{2}{*}{$\begin{array}{l}\text { Regional } \\
\text { Classification }\end{array}$} & \multicolumn{4}{c}{ Animal sourced food } & \multicolumn{2}{c}{ Non-Animal sourced food } & Total Food \\
\cline { 2 - 5 } & Value (rupiah) & $\%$ & Value (rupiah) & $\%$ & Value (rupiah) \\
\cline { 2 - 5 } Urban & 374,489 & 17.69 & $1,741,950$ & 82.31 & $2,116,439$ \\
Rural area & 233,623 & 14.24 & $1,407,288$ & 85.76 & $1,640,911$ \\
\hline
\end{tabular}

Source: Own calculation based on data from Susenas, 2017

Table 4: Food expenditures as classified by regions in West Java province 2017.

\begin{tabular}{ccccc}
\hline \multirow{2}{*}{ Years of Schooling } & \multicolumn{4}{c}{ Food Expenditures } \\
\cline { 2 - 5 } & \multicolumn{2}{c}{ Animal sourced food } & \multicolumn{2}{c}{ Non-Animal sourced food } \\
\cline { 2 - 5 } & Value (rupiah) & $\%$ & Value (rupiah) & $\%$ \\
\hline$<=9$ & 239,370 & 14.50 & $1,411,933$ & 85.50 \\
$>9$ & 505,660 & 19.61 & $2,072,558$ & 80.39 \\
\hline
\end{tabular}

Source: Own calculation based on data from Susenas, 2017

Table 5: Food expenditures according to education of the head of household in West Java province.

\begin{tabular}{lccccc}
\hline \multirow{2}{*}{ Income level } & \multicolumn{5}{c}{ Food Expenditures } \\
\cline { 2 - 5 } & \multicolumn{4}{c}{ Animal sourced food } & \multicolumn{2}{c}{ Non-Animal sourced food } & Total Food \\
\cline { 2 - 5 } & Value (rupiah) & $\%$ & Value (rupiah) & $\%$ & Value (rupiah) \\
\hline \multirow{2}{*}{ Low } & 128,142 & 13.19 & 843,014 & 86.81 & 971,155 \\
Middle class & 302,698 & 14.97 & $1,719,066$ & 85.03 & $2,021,764$ \\
High & 763,747 & 20.30 & $2,998,798$ & 79.70 & $3,762,545$ \\
\hline
\end{tabular}

Source: Own calculation based on data from Susenas, 2017

Table 6: Food Expenditures According to Household Income Levels in West Java.

Households with higher income tend to consume animal-sourced foods, consequently more expensive, than those with lower income. Lowincome groups consumed more fish, followed by eggs and poultry, and consumed very little meat and milk. In contrast to households with high income, albeit being dominated by fish, the expenditure of poultry, eggs, and milk is evenly distributed. This is in line with Abdulai's (2002) research which stated that the demand for meat and fish would increase along with the increase in consumer income, the research also expresses similar results by Hayat, Hussain and Yousaf (2016) which stated that higher household income would lead to an increase in household demand for dairy and meat products. The findings above are also in line with Bennet's Law stated that increasing income results in decreasing consumption of staple food. The consumption pattern is influenced by income, the wealthier a society is, the more varied its food consumption; initially dominated by simple starchy plants and later diversifying to plant-sourced food, fruit, dairy products, and especially meat.

\section{Estimating parameters of the animal sourced} food demand system model

Overcoming endogeneity required an instrumental variable, i.e., the total household income against the total household expenditure by adding food and non- food expenditures. According to Bopape (2006) and Fashogbon et al. (2012), the total income is a useful instrumental variable as it is correlated with the instructed variables and did not correlate with errors in the main equation. The disregard of blank data or zero consumption will lead to selectivity bias that will affect the estimation results. This study overcame it by adding the Inverse Mills Ratio (IMR) variable to the equation.

The effect of the own-price variable on each group of animal-sourced food commodities suggested a positive and significant for the group's expenditure share. The coefficient prices showed that should price increase by $1 \%$; the expenditure share would also be felt by the food groups; fish groups with $0.236 \%$ followed by eggs with $0.192 \%$, poultry with $0.172 \%$, milk with $0.091 \%$, and the lowest was the meat with $0.053 \%$, assuming 
ceteris paribus. This is in line with Abdulai's (2002) research, which stated that the own-price variable significantly influenced the increase of the expenditure share of the food commodity group, and prices affected all food commodities demand. Thus price policy as an agricultural policy instrument is fundamental.

Income variables demonstrate a positive relation with expenditure share. Thus, an increase in income will be followed by an increase in expenditure share. The coefficients for meat, egg, and milk commodity groups have a positive influence; an increase in income increase will be followed by an increase in group share. This finding is in line with Hayat, Hussain and Yousaf (2016), which stated that an increased household income would lead to increased demand for dairy and meat commodities. However, fish and poultry commodity groups have a negative coefficient; an increase in income will be followed by a decrease in the expenditure share of the dairy and meat commodities. This relation is likely to occur as an increase in household income will shift the demand towards more expensive animalsourced food like meat and milk. These phenomena demonstrated the application of Bennet's Law in West Java Province, namely the high income would shift the consumption pattern towards better quality food.

Regional dummy variables indicated that fish groups had a positive relation; household expenditure share for animal-sourced food commodities is higher in households living in urban areas compared to rural areas. Conversely, the expenditure share of milk commodity is lower for households living in urban areas compared to those living in rural areas. The comparison reflects the significant role that milk plays to fulfill the nutritional adequacy of children in rural areas, and the non-substitutable characteristic of milk, especially baby formula.

The years of schooling variables show that the years of schooling provides significance at the level of $1-10 \%$ of the poultry and milk groups. The years of schooling have a positive relation with the share of poultry expenditure but have a negative effect against the share of milk expenditure. Research conducted by Capps and Smith (1991) in Nugroho (2015) on the effect of health and nutritional factors in the analysis of food demand, described that demand by consumers is not only influenced by prices and income but also by other variables such as perceptions and product information.
The size of the household (the number of household members) had a significant influence on the level of $1-10 \%$ in the egg commodity group, which means that the size of the household influences the demand for eggs. This study indicated a negative effect between household size and share of egg expenditure. This negative effect indicated that the bigger the household, the smaller the expenditure for eggs. According to Mittal (2010), food is a private item that is difficult to substitute, especially for poor households. With per capita resources as constant, food consumption per capita should rise as household size increases. In fact, the more the family members, the less the food consumption. This phenomenon is called the Deaton-Paxson paradox proposed by Deaton and Paxson (1998). The study conducted by Deaton and Paxson (1998) in several countries: The United States, the United Kingdom, France, Taiwan, Thailand, Pakistan, and South Africa, indicated the negative correlation between the number of family members and the demand for food. This is because food consumed by people cannot be substituted with cheaper public goods, particularly in lowincome countries. This result is different for rice; a household with more infants and adults consumes more rice. This implies that a household with more household members spends a higher proportion on various at-home foods such as rice. Abdulai (2010) also stated that parameters related to household size affect consumption patterns; large families are often forced to adjust their consumption patterns to buy the relatively cheaper commodity, as indicated by the low egg consumption in West Java province of $10 \mathrm{~kg} /$ capita/year. Meanwhile, the consumption of chicken meat and eggs in Asian countries has now reached $15 \mathrm{~kg} /$ capita, and some have even reached $20 \mathrm{~kg}$ /capita (West Java Provincial Government, 2015).

The sex of the head of household is significant at the $1-5 \%$ real level for poultry and egg groups. Eggs have a positive effect if the sex of the head of the household is male, and poultry has a negative effect. A positive effect means that households with a male head of household consume $0.011 \%$ more eggs compared to households with a female household; whereas female head of household will rely on poultry to meet animal-sourced food needs. Pangaribowo and Tsegai (2011) examined the same thing for the sex dummy of the head of household (male), which gave a positive and negative relation. Usually, a positive relation is shown on higher quality and more expensive foods such as meat. The implication is that the difference in sex 
of the head of household leads to differences in consumers' behavior. This condition indicates that food policies should take the difference in sex of the head of household characteristics into consideration.

The Inverse Mills Ratio (IMR) is significant at the $60 \%$ coefficient, reflecting the problem of selectivity bias sample. This problem was overcome by adding the IMR variable to unbias the estimation parameters in the equation. Thus, the insignificant IMR variables with a $40 \%$ coefficient show that the selectivity bias problem does not occur for these commodity groups (Table 7).

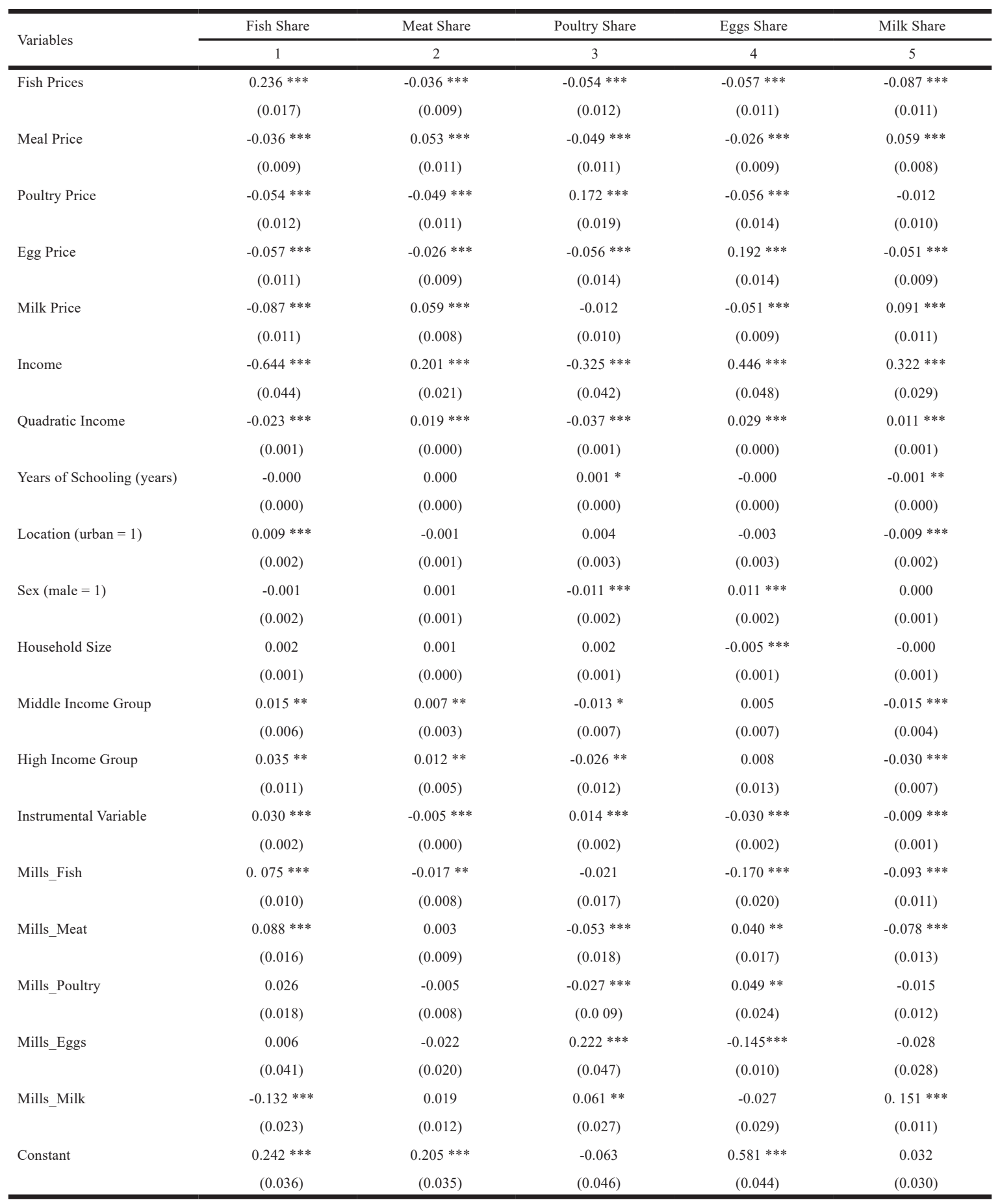

Note: $* * * \mathrm{p}<0.01, * * \mathrm{p}<0.05, * \mathrm{p}<0.1$. Standard errors in parentheses

Source: Own calculation based on data from Susenas, 2017

Table 7: The result from QUAIDS model of West Java province. 


\section{Income Elasticity}

The result showed that the demand income elasticity for household animal-sourced food in West Java had a positive relation; all groups of animal-sourced foods were categorized as normal goods, and there were no inferior goods. The value of income elasticity is shown in Table 8 below. In general, income elasticity for animal-sourced food in urban areas is lower tha in rural areas. This comparison indicated that from an economic standpoint, foods commodity are more affordable for urban households than rural households as the income of urban households on average is higher than rural households.

Income elasticity for meat is very responsive, even in rural areas the value is more than 2 . Thus, a $1 \%$ income increase will cause a consumption increase of this food group, assuming ceteris paribus. The high value of meat elasticity can be caused by meat's high prices, making meat a food group as the first choice should an income increase happen. On the other hand, urban areas have a smaller value as urban areas as it tends to have a higher increase in income.

For meat demand, the income elasticity will become smaller as income increases. This finding in line with the research conducted by Bopape (2007) and Faharudin et al. (2015) which stated that meat and fish are luxury goods in all household groups. Expenditure on meat and fish is more elastic among rural and low-income households than among urban households and high-income households. The same findings are found in the research conducted by Akinwumi et al. (2011) in Alimi (2013) which stated that beef and chicken are the most preferred meat and the level of household income strongly influenced the demand.

Meanwhile, the high-income households' groups have a 0.889 high-income elasticity for poultry, which means that changes in demand will be lower than changes in income. The $\mathrm{HoH}$ with less than or equal to 9 years of schooling is more responsive than $\mathrm{HoH}$ with more than nine years of schooling. The lower elasticity value of poultry compared to meat indicated that poultry is one of the mainstays of the community in meeting animal protein needs in West Java. DKPP West Java Province (2018) stated that $65 \%$ of West Java households still rely on poultry such as chickens and ducks as the main protein intake. Presently, the consumption of protein sources other than poultry food, both fish and meat, is still low, changing it will be difficult and will require a long process.

Eggs were one of the most consumed commodities by all levels of households because they contain high-quality, practical proteins, are easy to prepare, and are the cheapest among other animal-sourced food commodities. The value of income elasticity for egg commodities is positive, indicating eggs as normal goods. Thus, any increase in household income will cause the share of egg expenditure to increase. The income elasticity for eggs is the lowest compared to other animal-sourced food groups and is worth less than one.

Milk has complete nutritional content and is very beneficial for the health and human body. The value of milk's income elasticity is positive; this indicated that an increase in household income would cause the share of milk expenditure to increase. Milk is categorized as luxury goods which contrasted with other animal-sourced food groups. Thus, the higher the income, the more responsive to the demand it is, which means that high-income household will prioritize demand for milk if there is an increase in income. This finding is in line with Fabiosa (2005) which stated that the increasing consumption levels of animal-sourced protein are dairy products and poultry, this increased demand for animal-sourced food products is in line with increasing economic growth and urbanization.

\begin{tabular}{lccccccc}
\hline \multirow{2}{*}{$\begin{array}{c}\text { Animal Sourced } \\
\text { food }\end{array}$} & \multicolumn{2}{c}{ Region } & \multicolumn{2}{c}{ Education } & \multicolumn{3}{c}{ Income } \\
\cline { 2 - 7 } & City & Village & $<=9$ years & $>9$ years & Low & Middle class & High \\
\hline Fish & 1.073 & 1.036 & 1.050 & 1.086 & 1.084 & 1.054 & 1.032 \\
Meat & 1.748 & 2.210 & 1.998 & 1.681 & 1.944 & 1.968 & 1.631 \\
Poultry & 1.116 & 1.310 & 1.275 & 1.005 & 1.464 & 1.117 & 0.889 \\
Egg & 0.341 & 0.425 & 0.410 & 0.260 & 0.436 & 0.352 & 0.126 \\
Milk & 1.236 & 1.306 & 1.310 & 1.186 & 1.240 & 1.247 & 1.250 \\
\hline
\end{tabular}

Source: Own calculation based on data from Susenas, 2017 


\section{Own-price elasticity}

The value of the own-price elasticity for animalsourced food commodities is shown in Table 9. The elasticity value showed that all groups are negative, which means that the increase in commodity prices would cause a decrease in the consumption demand of the commodity, assuming ceteris paribus.

When viewed from absolute value, own-price elasticity has a value of less than one or is inelastic. This means that the percentage change in price is higher than the percentage change in demand; if there is a $1 \%$ increase in commodity prices, there will be a decline in commodity quantity of $0.399 \%$ for fish, $0.781 \%$ for meat, $0.320 \%$ for poultry, $0.178 \%$ for eggs and $0.333 \%$ for milk, assuming ceteris paribus.

Among the five groups of animal-sourced foods, the most inelastic is the egg group as it has the lowest own-price elasticity value, which is equal to 0.178 . This condition occurred as eggs are a cheap source of animal-sourced food with high nutrient content, becoming a mainstay of households in West Java in meeting the needs of animal protein. Thus, price increase was not responded by the household. The highest price elasticity was in the meat group, which is relatively more expensive. Meat commodity group has a price elasticity of 0.781 ; thus, the increase in food prices in households is almost proportional to the decrease in consumption of each food commodities, assuming ceteris paribus.

Meat and milk are more responsive in urban areas compared to rural areas. Thus, the higher the level of education and income, the more responsive the demand will be. However, it is not so for groups of fish, poultry, and eggs. The own-price elasticity showed that the higher the income group, the lower the value of elasticity, or the smaller the response value against the increase in education and income. This comparison indicated that households continuously try to maintain the quantity of consumption of fish, poultry, and eggs despite price increases. In West Java, when viewed based on the share of each group, fish, poultry, and eggs has the highest consumption compared to meat and milk groups, as prices are more affordable.

\section{Cross-price elasticity}

Cross-price elasticity showed the effect of price changes in other commodity groups against the demand for commodity groups. A positive value of the cross-price elasticity indicated that a price increase of a commodity group would increase the demand for other commodity groups or be substituted. Whereas a negative value indicated that a price increase of a commodity group would reduce the demand for other commodity groups or be complementary. The value of cross-price elasticity in this study resulted from 20 compositions is shown in Table 10 below.

\begin{tabular}{lcccccccc}
\hline \multirow{2}{*}{$\begin{array}{l}\text { Animal Sourced } \\
\text { Food }\end{array}$} & \multirow{2}{*}{ Total } & \multicolumn{2}{c}{ Region } & \multicolumn{2}{c}{ Education } & \multicolumn{2}{c}{ Income } \\
\cline { 3 - 8 } Fish & & City & Village & $<=9$ years & $>9$ years & Low & Middle Class & High \\
Meat & -0.399 & -0.347 & -0.485 & -0.454 & -0.268 & -0.497 & -0.372 & -0.276 \\
Poultry & -0.781 & -0.821 & -0.632 & -0.705 & -0.863 & -0.600 & -0.772 & -0.905 \\
Egg & -0.320 & -0.290 & -0.388 & -0.369 & -0.244 & -0.419 & -0.357 & -0.163 \\
Milk & -0.178 & -0.135 & -0.255 & -0.252 & 0.020 & -0.361 & -0.118 & 0.298 \\
\hline
\end{tabular}

Source: Own calculation based on data from Susenas, 2017

Table 9: Own price elasticity.

\begin{tabular}{lccccc}
\hline \multirow{2}{*}{ Animal sourced food } & \multicolumn{5}{c}{ Commodity Group } \\
\cline { 2 - 6 } & Fish & Meat & Poultry & Egg & Milk \\
\hline Fish & & -0.063 & -0.205 & -0.167 & -0.222 \\
Meat & -0.611 & & -0.575 & -0.342 & 0.470 \\
Poultry & -0.403 & -0.141 & & -0.294 & -0.022 \\
Egg & -0.004 & -0.011 & -0.069 & & -0.110 \\
Milk & -0.765 & 0.335 & -0.063 & -0.428 & \\
\hline
\end{tabular}

Source: Own calculation based on data from Susenas, 2017 
Table 10 shows only two commodities with a substitution effect with other animalsourced food groups, namely meat, and milk; the substitution relation to meat is milk. This substitution demonstrates that a $1 \%$ increase in meat will increase the demand for milk by $0.335 \%$, assuming ceteris paribus. While other commodities such as fish, poultry, and eggs are complementary to meat commodities, which means an increase in meat prices will decrease the demand for these three commodity groups. Thus, the substituting commodity of meat as a source of animal-sourced food is milk. Meanwhile, milk has a substitution effect with meat, meaning that a $1 \%$ increase in milk prices will increase demand for meat, which is equal to $0.470 \%$, assuming ceteris paribus. While other commodities such as fish, poultry, and eggs are complementary to dairy commodities, which means an increase in milk prices will decrease the demand for the three groups.

\section{Conclusion}

The result showed that the independent variables, i.e., price, income (expenditure approach) and demographic, socio-economic characteristics in the Quadratic Almost ideal demand System (QUAIDS) model could be used in estimating the share of animal-sourced food expenditure at the household level. The price variable, both the own-price and the cross-price of other animalsourced foods are mostly positive and negative in determining the share of each group. The income and squared income of a household are significant for the share of animal-sourced food group.

The income elasticity showed that all animalsourced food groups are categorized as normal goods, characterized by an income elasticity value of more than zero. The value of income elasticity for meat commodities is the highest and eggs are the lowest. The demand for meat will provide the highest response if there is an increase in income. However, eggs have the lowest response.
The own-price elasticity showed that the most responsive commodity is meat, followed by fish, poultry milk, and eggs. The five groups of commodities have a value of negative elasticity, which means that increasing commodity prices decrease the demand in the form of a reduced share of expenditure. While the cross-price elasticity of animal-sourced food commodity groups identified most groups as having a negative value, further proving that the related animal-sourced food commodity groups are complementary. Meanwhile, the meat and milk group have a substitution effect; the commodities that can replace meat as a source of animal protein is milk and vice versa.

\section{Policy implications and recommendations}

The income elasticity is higher than the value of price elasticity, meaning that the most effective way to direct the pattern of food consumption in West Java is through increasing people's income. Although price policy is crucial, in the long run, changes in the pattern of food consumption are primarily determined by the increase in people's welfare in the form of increased income.

Government policy priorities related to food and nutrition are prioritized for groups of people who live in rural and low-income areas. The order of consumption of high animal-sourced foods is fish and eggs, followed by poultry meat, especially from chicken. The demand or consumption of beef is relatively low. Thus, the government should encourage self-sufficiency in animal protein to ensure that various layers of society can feel the benefits. Diversification of food is a difficult task for the provincial government.

Diversification efforts include campaigns or outreach on the consumption of diverse, nutritious, and safe food for the community. As it also involves aspects of community behavior, then developing food consumption policies must be made into a mass movement that involves not only the government but covers all elements of society.

\author{
Corresponding authors \\ Dr. Bayu Kharisma \\ Department of Economics, Faculty of Economics and Business \\ Universitas Padjadjaran, Bandung, Indonesia \\ E-mail: bayu.kharisma@unpad.ac.id
}




\section{References}

[1] Abdulai, A. (2002) "Household Demand for Food in Switzerland. A Quadratic Almost Ideal Demand System", Swiss Journal of Economics and Statistics (SJES), Vol. 138, No. 1, pp. 1-18. ISSN 2235-6282.

[2] Aepli, M. (2014) “Analysis of Final Demand for Food and Beverages in Switzerland”, Unpublished Ph.D. Thesis, ETH Zurich Switzerland. DOI 10.3929/ethz-a-010251132.

[3] Alimi, S. R. (2013) "Households Expenditure Pattern on Beef and Chicken of Selected Households in Akoko South-West LGA of Ondo State, MPRA Paper No. 52153.

[4] Ariningsih, E. (2004) "Study of Animal Protein Consumption in The Time of Economic Crisis in Java”, ICASERD Working Paper No. 28. [Online]. Available: https://pse.litbang.pertanian.go.id/ ind/pdffiles/WP_28_2004.pdf [Accessed: 1 Jan. 2019].

[5] Bopape, L. and Myers, R. (2007) “Analysis of Household Demand for Food in South Africa: Model Selection, Expenditure Endogeneity, and the Influence of Socio-Demographic Effects", African Econometrics Society Annual Conference, Cape Town, South Africa.

[6] BPS (2017) “Pengeluaran Untuk Konsumsi Penduduk Indonesia Per Provinsi” (In Indonesia), Maret 2017, Publikasi BPS. Jakarta.

[7] Burger, R. P., Coetzee, L. Ch., Kreuser, C. F. and Rankin, N. A. (2017) "Income and Price Elasticities of Demand in South Africa: An Application of The Linear Expenditure System", South African Journal of Economics, Vol. 85, N. 4, pp. 491-514. ISSN 1813-6982. DOI 10.1111/saje.12167.

[8] Deaton, A. and Paxson, C. (1998) "Economies of Scale, Household Size, and The Demand for Food", Journal of Political Economy, Vol. 106, No. 5, pp. 897-930. ISSN 00223808. DOI 10.1086/250035.

[9] DKPP West Java Province (2018) "Pola Pangan Harapan Provinsi Jawa Barat Tahun 2018" (In Indonesia), Bandung. [Online]. Available: http://dkpp.jabarprov.go.id/wp-content/ uploads/2018/04/POLA-PANGAN-HARAPAN-PROVINSI-JAWA-BARAT-TAHUN-2018.pdf. [Accessed: 20 March,, 2019].

[10] Fabiosa, J. F. (2005) “Growing Demand for Animal-Protein-Source Products in Indonesia: Trade Implications". CARD Report and Working Papers. 419. Iowa State University.

[11] Faharuddin, Mulyana, A., Yamin, M. and dan Yunita (2015) “Analisis Pola Konsumsi Pangan di Sumatera Selatan 2013: Pendekatan Quadratic Almost Ideal Demand System” (In Indonesia), Jurnal Agro Ekonomi, Vol. 33, No. 2, pp. 123-140. E-ISSN 2541-1527, ISSN 0216-9053. DOI 10.21082/jae.v33n2.2015.121-140.

[12] Hayat, N., Hussain, A. and Yousaf, H. (2016) "Food Demand in Pakistan: Analysis and Projections", South Asia Economic Journal, Vol. 17, No. 1, pp. 94-113. ISSN 1391-5614. DOI $10.1177 / 1391561415621826$.

[13] Hoang, L. V. and Glewwe, P. (2011) "Impacts of Rising Food Prices on Poverty and Welfare in Vietnam", Journal of Agricultural and Resource Economics, Vol. 36, No. 1, pp. 14-27. ISSN 10685502.

[14] IFPRI (2016) “Global Hunger Index: Getting to Zero Hunger”, Washington, DC (US): International Food Policy Research Institute. ISBN 9780896292260. DOI 10.2499/9780896292260.

[15] Majumder, A, Ray, R. and Kompal, S. (2012) “Calculating Rural-Urban Food Price Differentials from Unit Values in Household Expenditure Surveys: A Comparison with Existing Methods and A New Procedure", American Journal of Agricultural Economics, Vol. 94, No. 5, pp. 1218-1235. ISSN 0002-9092. DOI 10.1093/ajae/aas064.

[16] Mayasari, D., Satria, D. and Noor, I. (2018) “Analisis Pola Konsumsi Pangan Berdasarkan Status IPM di Jawa Timur” (In Indonesia), Jurnal Ekonomi dan Pembangunan Indonesia, Vol. 18, No. 2, pp. 191-213. ISSN 10685502. DOI 10.21002/jepi.v18i2.801. 
[17] Ministry of Health (2015) "Nutritional Status Affects Nation Quality", [Online]. Available: http://www.depkes.go.id/article/print/15021300004/status-gizi-pengaruhi-kualitas-bangsa.html. [Accessed: 10 Feb., 2019].

[18] Mittal, S. (2010) "Application of The Quaids Model to The Food Sector in India", Journal of Quantitative Economics, Vol. 8, No. 1. pp. 42-54. ISSN 0971-1554.

[19] Molina, J. E. and Gil, A. I. (2005) "The Demand Behavior of Consumers in Peru: A Demographic Analysis Using the QUAIDS", Journal of Developing Areas, Vol. 39, No. 1, pp. 191-206. ISSN 0022037X. DOI 10.1353/jda.2005.0038.

[20] Nugroho, S. and Suparyono, S. W. (2015) "Pola Permintaan Daging Tingkat Rumah Tangga di Indonesia: Analisa Data Mikro 2013" (In Indonesia), Jurnal Ekonomi dan Pembangunan Indonesia, Vol. 16 No. 1, Juli 2015: 47-58. ISSN 10685502. DOI 10.21002/jepi.v16i1.668.

[21] Pakpahan, A. (2018) "Pergeseran Dalam Indeks Kelaparan Global (Global Hunger Index) 20002017: Implikasi Terhadap Kebijakan Pertanian, Pangan, dan Kualitas Sumber Daya Manusia Indonesia" (In Indonesia), Jurnal Forum Penelitian Agro Ekonomi, Vol. 35, No. 2. ISSN 0216-4361. DOI 10.21082/fae.v35n2.2017.75-90.

[22] Pangaribowo, E. H. and Tsegai, D. W. (2011) "Food Demand Analysis of Indonesian Households with Particular Attention to the Poorest", Discussion Papers 116748, University of Bonn, Center for Development Research (ZEF). ISSN 1436-9931.

[23] Poi, B. P (2012) "Easy Demand-System Estimation with Quaids", The Stata Journal, Vol. 12, No. 3, pp. 433-446. E-ISSN: 1536-8734, ISSN 1536-867X. DOI 10.1177/1536867X1201200306.

[24] Ravallion, M. and Van de Walle, D. (1991) “The Impact on Poverty of Food Pricing Reforms: A Welfare Analysis for Indonesia", Journal of Policy Modeling, Vol. 13, No. 2, pp. 281-299. ISSN 0161-8938. DOI 10.1016/0161-8938(91)90015-Q.

[25] Ray, R. (1983) "Measuring the Costs of Children: An Alternative Approach", Journal of Public Economics, Vol. 22, No. 1, pp. 89-102. ISSN 0047-2727. DOI 10.1016/0047-2727(83)90058-0.

[26] West Java Provincial Government (2015) "Consumption Position of Chicken Meat and Eggs in West Java $10 \mathrm{Kg} /$ capita". [Online]. Available: http://www.jabarprov.go.id/index.php/ news/11686/2015/03/30/Posisi-Konsumsi-Daging-Ayam-dan-Telur-Di-Jabar-10-Kgkapita. [Accessed: 15 Feb. 2019].

[27] Widarjono, A. and Rucbha, S. M. (2016) "Household Food Demand in Indonesia: A Two-Stage Budgeting Approach", Journal of Indonesian Economy and Business, Vol. 31, No. 2, pp. 163-177. ISSN 2338-5847. DOI 10.22146/jieb.15287.

[28] Zheng, Z. and Henneberry, S. R. (2010) "The Impact of Changes in Income Distribution on Current and Future Food Demand in Urban China", Journal of Agricultural and Resource Economics, Vol. 35, No. 1, pp. 1-21. ISSN 10685502. 